\title{
The Endocrine Pancreas of the Fetus from Diabetic Pregnant Rat
}

\author{
A. Kervran, M. Guillaume, and A. Jost \\ Laboratoire de Physiologie du Développement, Collège de France, Paris, France
}

Summary. Diabetes was induced in female rats by streptozotocin administration prior to mating. Pregnant rats were divided into "severe diabetics" (blood glucose concentration above $300 \mathrm{mg} / 100 \mathrm{ml}$ ) and "mild diabetics" (blood glucose ranging from 100 to $200 \mathrm{mg} / 100 \mathrm{ml}$ ). When compared to control fetuses, fetuses from severely diabetic mothers showed a slight decrease of body weight on days 20.5 and 21.5. Fetal pancreatic insulin stores and plasma insulin concentrations were decreased at 19.5, 20.5 and 21.5 days. The insulin response to glucose was impaired both in vivo and in vitro. In contrast, fetuses from mildly diabetic females showed no change in body weight. Pancreatic and plasma insulin concentrations were increased at $19.5,20.5$ and 21.5 days. The response of the $\beta$ cells of term fetuses of mild diabetics to glucose stimulation was enhanced in vitro. These results are consistent with the hyperglycaemiahyperinsulinaemia theory with regard to the fetuses from mildly diabetic rats and with an impairment of insulin biosynthesis and release in fetuses from severely diabetic females.

Key words: Streptozotocin diabetes, mild diabetes, severe diabetes, fetus, pancreatic insulin, plasma insulin, insulin secretion, insulin disappearance rate.

The use of rats made diabetic by pancreatectomy, alloxan or streptozotocin as an animal model for human diabetic pregnancy has led to conflicting results with respect to fetal pancreatic function. Pan-

* Presented at the 13th Annual Meeting of the European Association for the Study of Diabetes. Diabetologia 13, 397 (1977) creatic insulin content of fetuses from diabetic pregnant rats has commonly been reported to be decreased $[1,2,3]$ or unchanged [4] compared to control fetuses. Similarly plasma insulin concentration was found to be lowered [5, 6, 7] unchanged [6] or increased $[4,7]$. Part of these divergent results may be because in most studies $[1,2,3,5]$ the severity of diabetes (i. e. the magnitude of the hyperglycaemia) was not taken into account. It has long been known that mildly diabetic pregnant rats delivered young with larger birth weights than controls whereas severe diabetics delivered small or normal weight fetuses [8]. Similarly it has recently been demonstrated that morphological and ultrastructural changes in the fetal endocrine pancreas of the rat are different in mild or severe diabetes [6].

The present study was designed to investigate the effects of either mild or severe maternal diabetes during the whole duration of pregnancy on some aspects of the development and functional maturation of the $\beta$ cells in the rat fetus.

\section{Materials and Methods}

\section{Animals}

Virgin female Sherman rats weighing 200 to $250 \mathrm{~g}$ were fed ad libitum with $\mathrm{UAR} \mathrm{BO}_{3}$ laboratory chow. They received an intravenous injection of 30 to $50 \mathrm{mg} / \mathrm{kg}$ body weight of streptozotocin (lot NSC 85998, National Cancer Institute) under light ether anaesthesia. Four days later blood glucose concentration was measured and the females were caged overnight with a male. The following morning was day 0.5 of gestation [9]. Females were divided into "mild diabetics" (glucose ranging from 100 to $200 \mathrm{mg} / 100 \mathrm{ml}$ ) and "severe diabetics" (blood glucose above $300 \mathrm{mg} / 100 \mathrm{ml}$ ). No glucose values between $200 \mathrm{mg}$ and $300 \mathrm{mg} /$ $100 \mathrm{ml}$ were obtained. Mother rats were screened by palpation at 14.5 days of gestation. Experiments were performed on days 19.5 to 21.5 of gestation without previous fasting. 


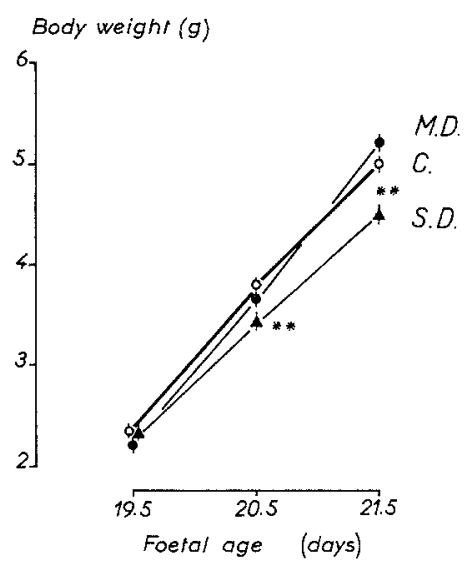

Fig. 1. Body weight changes during the last three days of gestation in fetuses from control (C.) mildly (M.D.) or severely (S. D.) diabetic pregnant rats. Vertical lines indicate \pm SEM. Significant differences between fetuses from mildly or severely diabetic rats and the controls are indicated by: ${ }^{* *} p<0.01$; there is no mention when $\mathrm{p}>0.05$

\section{Samples}

Pregnant rats were anaesthetized by an intraperitoneal injection of pentobarbital $(30 \mathrm{mg} / \mathrm{kg}$ body weight). Fetuses still connected to the mother by their umbilical cord were successively exteriorized from the uterus and blood specimens were collected with a heparinized Pasteur pipette after section of the brachial vessels. Plasma from each fetus was separated immediately and stored individually at $-20^{\circ} \mathrm{C}$ until assay.

Each fetus and placenta (without umbilical cord and membranes) were weighed. The pancreases of 5 fetuses per litter were dissected out, weighed individually and extracted in $2 \mathrm{ml}$ of an acid-alcohol solution (ethanol $75 \%(\mathrm{v} / \mathrm{v})$ distilled water $23.5 \%$ and concentrated hydrochloric acid $1.5 \% \mathrm{v} / \mathrm{v}$ ) by ultrasonic disintegration at $4{ }^{\circ} \mathrm{C}$ (MSE $\mathrm{MK}_{2}$ Crowley England). After centrifugation the supernatant was kept at $-20^{\circ} \mathrm{C}$ until assay.

\section{Disappearance Rate of ${ }^{131}$ I Insulin}

Severely diabetic or control mothers on day 21.5 of gestation were anaesthetized with pentobarbital. Fetuses were injected with $0.05 \mu \mathrm{Ci}$ of human ${ }^{131} \mathrm{I}$ insulin (Centre National de Transfusion Sanguine, Orsay, France) in the vitellin vein through the uterine horn [10]. Four fetuses were injected in each litter and fetal blood was collected $20,30,40$ and $50 \mathrm{~min}$ thereafter; this interval was chosen because it allowed ample time for equilibration in tissue fluids and accurate determination of the plasma radioactivity [11]. Paper chromatography on Whatmann $3 \mathrm{MM}$ was used to estimate the radioactivity remaining as intact ${ }^{131} \mathrm{I}$ insulin in plasma samples [12].

\section{Glucose Infusion}

Mother rats were anaesthetized with pentobarbital. The core temperature was maintained constant $\left(38^{\circ} \mathrm{C}\right)$ during the experiments by warming the mothers with an incandescent lamp. Glucose challenge was carried out on day 21.5 of gestation by a twostep administration of a $30 \mathrm{~g} / 100 \mathrm{ml}$ or $50 \mathrm{~g} / 100 \mathrm{ml}$ glucose solution into the maternal saphenous vein: 1) a loading dose of $1 \mathrm{ml}$ in two min, and 2) a constant infusion of $1.2 \mathrm{ml}$ over $60 \mathrm{~min}$. Five fetuses were collected for blood samples during the last $10 \mathrm{~min}$ of glucose infusion.

\section{Perifusion Procedure}

The perifusion apparatus and the procedure were that described by others [13]. Mother rats were anaesthetized with ether. Pancreases were rapidly removed from term fetuses and sectioned in pieces of approximately $0.5 \mathrm{~mm}^{3}$ using a McIlvain tissue chopper. Minced tissues were placed into small chambers $(5$ to $10 \mathrm{mg}$ in each of them) through which gassed Krebs-Ringer bicarbonate buffer containing $0.5 \mathrm{~g} / 100 \mathrm{ml}$ human serum albumin was pumped at a flow rate of $0.8 \mathrm{ml} / \mathrm{min}$. A $100 \mathrm{~min}$ prestimulatory period with buffer containing $40 \mathrm{mg} / 100 \mathrm{ml}$ of glucose was followed by a $40 \mathrm{~min}$ stimulatory period with glucose $250 \mathrm{mg} / 100 \mathrm{ml}$.

\section{Assays}

Blood glucose concentration was measured by a glucose oxidase method (Biochemica Test Combination, Boehringer, Mannheim). Plasma insulin levels were determined by radioimmunoassay using rat insulin as standard $(21.4 \mathrm{U} / \mathrm{mg}$; batch R 170 , Novo Industry, Denmark). The assay allows the determination of $6 \mu \mathrm{U} / \mathrm{ml}$ in $20 \mu \mathrm{l}$ plasma samples with a coefficient of variation of $10 \%$ [14]. Acetoacetate and $\beta$ hydroxybutyrate were determined with a microfluorimetric technique described previously [15].

The results are given as means \pm SEM. The significance of changes in the studied variables was determined by unpaired Student's $t$ test. When the number of observations in different experimental groups was too unequal, the non parametric WilcoxonMann-Whitney rank test was employed. Exponential parameters of the disappearance curves of ${ }^{131} \mathrm{I}$ insulin were estimated by a non-linear regression analysis using an iterative least squares method [16].

\section{Results}

\section{Fetal and Placental Weights}

The effect of streptozotocin diabetes on fetal weights during the last three days of gestation is shown in Figure 1 . In the severe diabetes group the weights were significantly less than in the two other groups on days 20.5 and 21.5 in spite of overlap between groups. There was no significant overweight in term fetuses from mildly diabetic mothers $(5.2 \pm 0.1 \mathrm{~g}$; $\mathrm{n}$ $=24$ ) when compared with the control group (5.0 $\pm 0.1 \mathrm{~g} ; \mathrm{n}=44 ; \mathrm{p}>0.05)$. The mean placental weight in term fetuses was greater in mild $(0.66$ $\pm 0.02 \mathrm{~g} ; \mathrm{n}=24)$ and in severe $(0.69 \pm 0.02 ; \mathrm{n}=33)$ diabetic animals than in controls $(0.49 \pm 0.01 \mathrm{~g} ; \mathbf{n}=$ $44 ; p<0.001)$. There was no linear correlation between fetal and placental weights and no difference in litter size in mild or severe diabetic and control groups $(11.0 \pm 0.7, \mathrm{n}=6 ; 10.7 \pm 0.7, \mathrm{n}=6$; and $11.8 \pm 0.4, \mathrm{n}=8$ respectively).

\section{Plasma Insulin, Blood Glucose and Ketone Bodies}

At 21.5 days of gestation no change in the blood concentration of ketone bodies was observed in the 

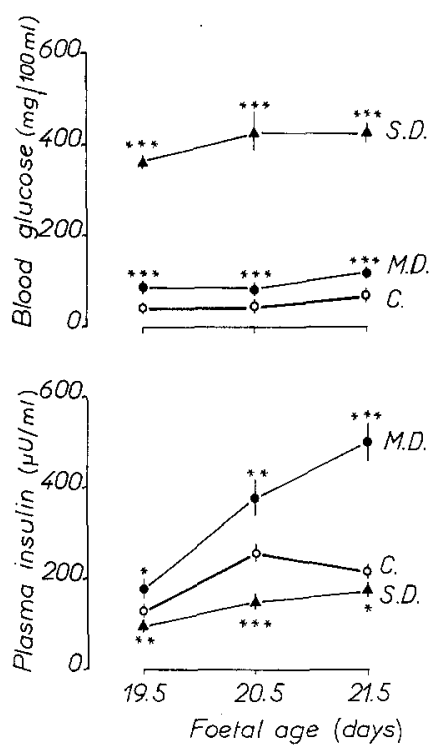

Fig. 2. Blood glucose and plasma insulin concentrations during the last three days of gestation in fetuses from control (C.) mildly (M. D.) or severely (S. D.) diabetic rats. Vertical lines: \pm SEM. Significant differences between diabetic groups and the control are indicated by: ${ }^{*} \mathrm{p}<0.05 ; * * \mathrm{p}<0.01$; *** $\mathrm{p}<0.001$

severe or mild diabetic groups compared with the control (Table 1). Figure 2 shows fetal blood glucose and plasma insulin levels during the last three days of gestation. In the control group, blood glucose remained low during this period $(44 \pm 2 \mathrm{mg} / 100 \mathrm{ml}$, $\mathrm{n}=17$ on day 19.5 ; and $45 \pm 4 \mathrm{mg} / 100 \mathrm{ml}, \mathrm{n}=21$ on day 20.5). Plasma insulin concentrations increased between day $19.5(127 \pm 10 \mu \mathrm{U} / \mathrm{ml}, \mathrm{n}=$ 17) and day $20.5(255 \pm 18 \mu \mathrm{U} / \mathrm{ml}, \mathrm{n}=21)$ and remained high the following day (Table 1 ). In mild diabetic animals, fetal blood glucose concentration on day 19.5 was twice as high as in controls (81 $\pm 9 \mathrm{mg} / 100 \mathrm{ml}, \mathrm{n}=5$ ), at that stage, the fetuses already showed marked hyperinsulinaemia (177 $\pm 21 \mu \mathrm{U} / \mathrm{ml}, \mathrm{n}=5, \mathrm{p}<0.05)$ which increased in magnitude with fetal age $(377 \pm 39 \mu \mathrm{U} / \mathrm{ml}, \mathrm{n}=14$ on day 20.5). In contrast, fetuses from severely diabetic mothers with blood glucose concentrations averaging $400 \mathrm{mg} / 100 \mathrm{ml}$, had a significantly reduced plasma insulin level on day $19.5(96 \pm 6 \mu \mathrm{U} / \mathrm{ml}, \mathrm{n}=$ $25, \mathrm{p}<0.01), 20.5(148 \pm 13 \mu \mathrm{U} / \mathrm{ml}, \mathrm{n}=14, \mathrm{p}<$ 0.001 ) and on day 21.5 (Table 1 ) in spite of some overlap in values at this stage.

\section{Pancreatic Insulin}

Table 2 shows data pertaining to pancreatic weight and insulin concentrations of fetuses from the three experimental groups, on day 19.5 to 21.5 of gestation. The mean pancreatic weights were significantly

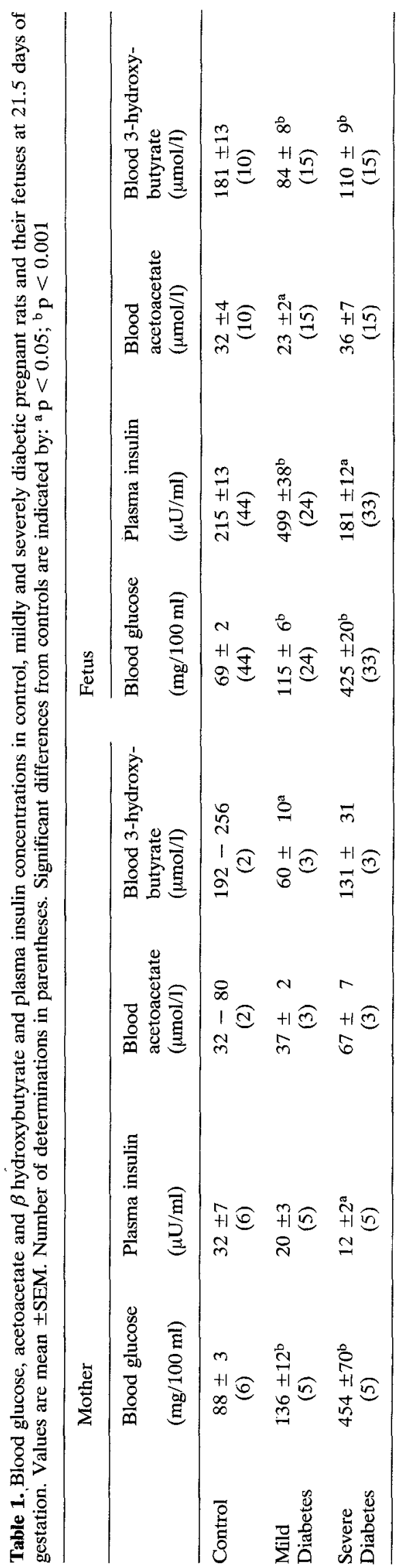


Table 2. Fetal pancreatic weight and insulin content in late pregnancy. Data from control, mild and severe diabetic pregnant rats. Means \pm SEM. Number of determinations in parentheses. Significant differences from controls are indicated by: ${ }^{\mathrm{a}} \mathrm{p}<0.05 ;{ }^{\mathrm{b}} \mathrm{p}<0.01 ;{ }^{\mathrm{c}} \mathrm{p}<0.001$

\begin{tabular}{|c|c|c|c|c|}
\hline Fetal age (days) & Pancreas & Mild diabetes & Control & Severe diabetes \\
\hline 19.5 & $\begin{array}{l}\text { Weight } \\
\text { (mg) } \\
\text { Insulin } \\
\text { (mU/mg) }\end{array}$ & $\begin{array}{c}10.4 \pm 1.2 \\
(5) \\
0.78 \pm 0.06\end{array}$ & $\begin{array}{c}10.1 \pm 1.5 \\
(5) \\
0.65 \pm 0.07\end{array}$ & $\begin{array}{c}12.5 \pm 2.1 \\
(10) \\
0.42 \pm 0.05\end{array}$ \\
\hline 20.5 & $\begin{array}{l}\text { Weight } \\
\text { (mg) } \\
\text { Insulin } \\
\text { (mU/mg) }\end{array}$ & $\begin{array}{c}19.7 \pm 1.3 \\
(10) \\
1.15 \pm 0.09^{c}\end{array}$ & $\begin{array}{c}17.2 \pm 0.5 \\
(15) \\
0.84 \pm 0.03\end{array}$ & $\begin{array}{c}12.3 \pm 1.3^{\mathrm{b}} \\
(5) \\
0.79 \pm 0.12\end{array}$ \\
\hline 21.5 & $\begin{array}{l}\text { Weight } \\
\text { (mg) } \\
\text { Insulin } \\
\text { (mU/mg) }\end{array}$ & $\begin{array}{c}30.8 \pm 1.3^{\mathrm{a}} \\
(15) \\
1.80 \pm 0.12^{\mathrm{b}}\end{array}$ & $\begin{array}{c}27.4 \pm 0.8 \\
(19) \\
1.36 \pm 0.08\end{array}$ & $\begin{array}{c}27.0 \pm 0.8 \\
(27) \\
0.69 \pm 0.06^{\mathrm{c}}\end{array}$ \\
\hline
\end{tabular}

Table 3. Insulin release by perifused fetal rat pancreas on day 21.5 from control, mild or severe diabetic female rats in response to glucose. The average rates of insulin release were calculated from data shown in Figure 4 . Significant differences between mild or severe diabetes and the controls are indicated by: ${ }^{\mathrm{a}} \mathrm{p}<0.001$

\begin{tabular}{|c|c|c|c|c|c|c|}
\hline & \multirow[b]{2}{*}{$\mathrm{n}$} & \multirow{2}{*}{$\begin{array}{l}\text { Prestimulatory phase } \\
\left(\mathbf{t}_{-10}-\mathbf{t}_{0}\right) \\
\text { Insulin release } \\
(\mu \mathrm{U} / \mathrm{min} / \mathrm{mg})\end{array}$} & \multicolumn{2}{|l|}{$\begin{array}{l}\text { First phase } \\
\left(t_{0}-t_{10}\right)\end{array}$} & \multicolumn{2}{|l|}{$\begin{array}{l}\text { Second phase } \\
\left(t_{10}-t_{40}\right)\end{array}$} \\
\hline & & & $\begin{array}{l}\text { Insulin release } \\
(\mu \mathrm{U} / \mathrm{min} / \mathrm{mg})\end{array}$ & $\begin{array}{l}\% \text { of basal } \\
\text { rate }\end{array}$ & $\begin{array}{l}\text { Insulin release } \\
(\mu \mathrm{U} / \mathrm{min} / \mathrm{mg})\end{array}$ & $\begin{array}{l}\% \text { of basal } \\
\text { rate }\end{array}$ \\
\hline Control & 16 & $0.55 \pm 0.05$ & $1.23 \pm 0.05$ & 224 & $1.58 \pm 0.06$ & 287 \\
\hline $\begin{array}{l}\text { Mild } \\
\text { diabetes }\end{array}$ & 12 & $0.71 \pm 0.12$ & $1.84 \pm 0.08^{\mathrm{a}}$ & 259 & $2.63 \pm 0.15^{\mathrm{a}}$ & 370 \\
\hline $\begin{array}{l}\text { Severe } \\
\text { Diabetes }\end{array}$ & 12 & $0.44 \pm 0.06$ & $0.59 \pm 0.06^{\mathrm{a}}$ & 134 & $0.48 \pm 0.03^{\mathrm{a}}$ & 109 \\
\hline
\end{tabular}

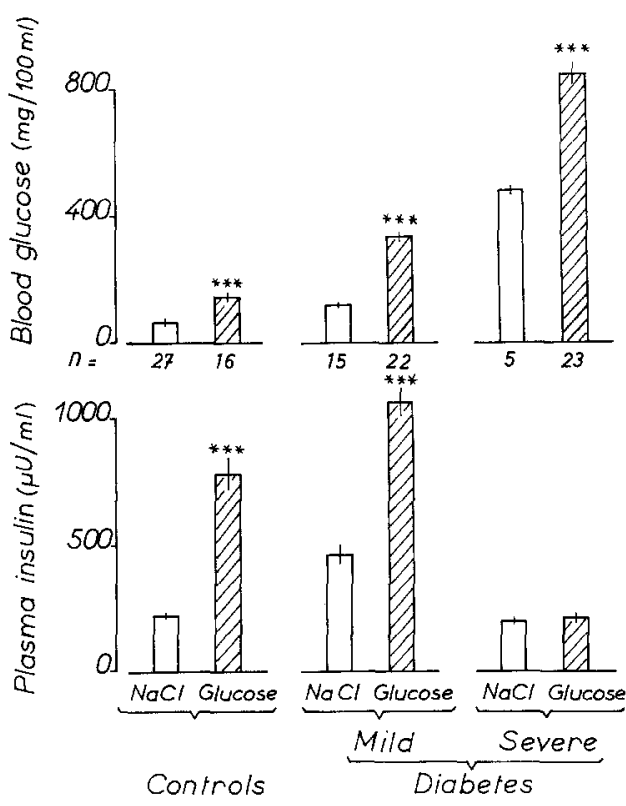

Fig. 3. Blood glucose and plasma insulin levels in fetuses on day 21.5 after a one hour glucose or saline infusion into the mothers. Number of determinations is given on the line $n=\ldots$ Vertical lines indicate \pm SEM. Significant differences between glucose and saline are indicated by: ${ }^{* * *} \mathrm{p}<0.001$

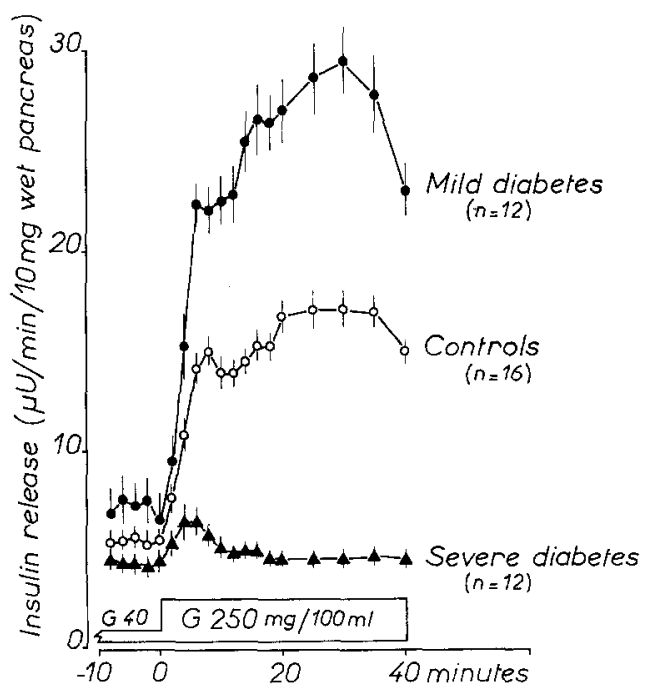

Fig. 4. Effect of glucose $250 \mathrm{mg} / 100 \mathrm{ml}$ on insulin secretion by perifused fetal rat pancreas on day 21.5 from control, mildly or severely diabetic females. The stimulation is preceded by $100 \mathrm{~min}$ prestimulatory period of which the last $10 \mathrm{~min}$ are shown. ( ) = number of experiments. Vertical lines $= \pm \mathrm{SEM}$ 
greater in the mildly diabetic group on day 21.5 and smaller in severe diabetics on day 20.5 compared with the corresponding controls. The mean fetal pancreatic insulin concentrations were significantly lower in severe diabetes fetuses on day 21.5 and greater in mild diabetes on days 20.5 and 21.5 than in the control groups.

\section{${ }^{131}$ I Insulin Disappearance Rate}

One disappearance curve was calculated in each experimental group; the four fetuses injected in the same litter were successively sacrificed after 20,30 , 40 and 50 minutes. There was no statistical difference in the disappearance rate (in term of comparison between the slopes) between fetuses of the severe diabetes mothers $\left(\mathrm{t}_{1 / 2}=24.9 \pm 8.9 \mathrm{~min}, \mathrm{n}=\right.$ 12 in three litters) and controls $\left(\mathrm{t}_{1 / 2}=21.1 \pm 2.2 \mathrm{~min}\right.$, $\mathrm{n}=24$ in six litters).

\section{Fetal Response to Glucose in Vivo}

The response of the pancreas to one hour of hyperglycaemia induced by glucose infusion into the mothers was studied in term fetuses in utero. Experiments were carried out so as to obtain for each group an approximately twofold increase of the fetal blood glucose. As shown in Figure 3, one hour of hyperglycaemia in control and mildly diabetic mothers, induced a threefold and a twofold increase in the fetal plasma insulin respectively, compared with fetuses from saline-infused females. In fetuses from severely diabetic females the twofold increase of the blood glucose over a period of one hour did not induce any significant rise in plasma insulin concentration.

\section{Pancreatic Response to Glucose in Vitro}

The dynamics of insulin release obtained by in vitro perifusion of pieces of term fetal rat pancreas are shown in Figure 4. In the control group, the passage from low to high glucose concentration induced a threefold rise in the insulin release and the response was biphasic. In basal conditions (glucose $40 \mathrm{mg}$ / $100 \mathrm{ml}$ ) there was no significant difference between insulin release from fetal pancreas of mildly or severely diabetic and control mothers (Table 3). In the mild diabetes fetuses the magnitude of the response to high glucose medium $(250 \mathrm{mg} / 100 \mathrm{ml})$ was significantly higher than in controls. In the severe diabetes fetuses, the passage from low to high glucose concentration induced only a small transient rise in the insulin secretion rate over the first 10 minutes of stimulation. The stimulation of these pancreases with a higher glucose concentration $(800 \mathrm{mg} / 100 \mathrm{ml})$ did not further modify the insulin release. It was not possible to express the insulin release as a function of the pancreatic insulin content. There was a large and nonspecific insulin release during the preparation of the pieces of pancreatic tissue.

\section{Discussion}

One feature of the infants of women with a mild form of diabetes is their increased birth-weight, mainly due to hypertrophy of their adipose tissue [17]. This has been attributed to hyperinsulinism which develops during fetal life in response to maternal hyperglycaemia [18, 19]. In our experiments mild diabetes did not induce a significant increase in fetal weight on day 21.5 in spite of marked fetal hyperinsulinism. This observation confirms some previous data $[4,6]$ but disagrees with others reporting increased weight in fetuses from mildly diabetic pregnant rats $[8,20$, review in 9]. The reasons for this discrepancy remain unclear; the short duration of pregnancy in the rat and the poor development of adipose tissue in term fetuses (approximately $1 \%$ ) compared to that of human babies (averaging 16\%) could account for the difference between rats and humans. In contrast growth retardation is reported in infants of women with longstanding and complicated diabetes [21]. In severely diabetic rats the fetal growth retardation observed by us and others $[6,22$, 23] may be due to decreased basal plasma insulin levels [5, 6 and Fig. 2) associated with an impairment of the response of the $\beta$ cells to glucose (Fig. 4). Maternal hyperketonaemia as an explanation for reduced fetal weight seems unlikely since at term the blood concentration of ketone bodies in the severely diabetic rats was not different from those in the controls (Table 1). However other alteration of the nutritional environment or in the placental transfer of substrates cannot be excluded.

The infants of diabetic women show hyperplasia and a hypertrophy of their islets of Langerhans [24, $25]$ together with increased pancreatic insulin content $[25,26]$. In the rat similar morphological changes have been demonstrated in fetuses from mildly diabetic females [6] while $\beta$ cells of fetuses from severely diabetic mothers are degranulated $[6$, 27] or possibly ungranulated. The high and low pancreatic insulin content we observed in fetuses of mild and severe diabetic mothers, corroborate these histological data and the recent findings that insulin biosynthesis was increased in mild and reduced in severe diabetic fetuses [28]. The "deleterious" effects of high glucose concentrations on the pan- 
creatic insulin content have been observed when fetal pancreases were grown in organ culture with high glucose-containing media [29].

Mild maternal diabetes enhances the blood glucose level in the fetuses, which in turn develop marked hyperinsulinism; this is conspicuous already on day 19.5; earlier stages were not studied. This confirms previous studies in the rat $[4,6]$ and is consistent with the hyperglycaemia-hyperinsulinaemia theory proposed for the infants of diabetic women $[18,29]$. The decreased plasma insulin concentration of the severe diabetic fetuses $[5,6,7]$ cannot be explained by an increase in the turnover rate of insulin in blood since the disappearance curves of 131 insulin in vivo and the insulin secretion rate in vitro were not significantly different from control fetuses.

The ability of the term rat fetus to increase its plasma insulin concentration in vivo in response to glucose agrees with previous report $[30,31,32]$. Our present data confirm that in vitro glucose induces a clear biphasic insulin release by pieces of term fetal pancreas during a 40 minute stimulation [33] as shown in vivo [32]. The pancreas of the fetuses from mildly diabetic rats responded in vivo to the one hour of hyperglycaemia with an increase in plasma insulin in spite of a high basal plasma insulin and also displayed in vitro an enhanced response to glucose. This suggests an incrsased sensitivity of the fetal pancreas to this stimulus. In contrast the pancreases of the fetuses from severely diabetic rats failed to respond in vivo to a one hour glucose load and in vitro were almost unresponsive to glucose. Insensitivity rather than a shift of the glucose-insulin dose-response curve is suggested since in vitro a very high glucose concentration $(800 \mathrm{mg} / 100 \mathrm{ml})$ failed to increase further the insulin secretion rate. It is not yet possible from our results to assess the reason for this impaired sensitivity to glucose. The presumed low pancreatic insulin content, as well as possible alterations of glucose metabolism in the $\beta$ cells, may be candidates.

Acknowledgements. We thank Jean-Paul Pégorier for determinations of the blood ketone bodies. These studies were supported by grants from the DGRST (contract $\mathrm{N}^{\circ} 76-7-1539$ ) and from the INSERM (ATP 55-77-87).

\section{References}

1. Dixit, P. K., Lowe, I. P., Heggestad, C. B., Lazarow, A.: Insulin content of microdissected fetal islets obtained from diabetic and normal rats. Diabetes 13, 71-77 (1964)

2. Golob, E. K., Rishi, S., Becker, K. L., Moore, C., Shah, N.: The effect of streptozotocin-induced diabetes on pancreatic insulin content of the fetus. Diabetes 19, 610-613 (1970)
3. Lambert, A. E., Kanazawa, Y., Halter, J. B., Orci, L., Rouiller, C., Renold, A. E.: Insulin release from fetal and newborn rat pancreas in vitro. Role of the adenyl cyclase system. Acta Diabetol. Lat. 7, 229-261 (1970)

4. Pitkin, R.M., Van Orden, D. E.: Fetal effects of maternal streptozotocin diabetes. Endocrinology 94, 1247-1253 (1974)

5. Heggestad, C. B., Morgan, C. R., Lazarow, A.: Insulin levels in maternal and fetal plasma from normal and alloxan diabetic rats near term. Anat. Rec. 151, 455-456, (Abst.) (1965)

6. Aerts, C., Van Assche, F. A.: Rat fetal endocrine pancreas in experimental diabetes. J. Endocrinol. 73, 339-346 (1977)

7. Clark, C. M. jr., Cahill, G. F. jr., Soeldner, J. S.: Effects of exogenous insulin on the rate of fatty acid synthesis and glucose $C^{14}$ utilization in the twenty-day rat fetus. Diabetes $\mathbf{1 7}$, 362-368 (1968)

8. Solomon, F.: Embryomegaly and increased fetal mortality in pregnant rats with mild alloxan diabetes. Diabetes 8, 45-50 (1959)

9. Jost, A., Picon, L.: Hormonal control of fetal development and metabolism. Adv. Metab. Disord. 4, 123-184 (1970)

10. Jost, A., Petter, C., Duval, G., Maltier, J. P., Roffi, J.: Action de l'adrénaline sur le partage du sang entre le foetus et le placenta: facteurs hémodynamiques de certaines lésions congénitales des extrémités (acroblapsie). C. R. Acad. Sci. [D] (Paris) 259, 3086-3088 (1964)

11. Goodner, C. J., Freinkel, N.: Carbohydrate metabolism in pregancy: the turnover of ${ }^{131} \mathrm{I}$ insulin in the pregnant rat. Endocrinology 67, 862-872 (1960)

12. Berson, S. A., Yalow, R. S., Bauman, A., Rothschild, M. A., Newerly, K.: Insulin ${ }^{131}$ I metabolism in human subjects: demonstration of insulin binding globulin in the circulation of insulin treated subjects. J. Clin. Invest. 35, 170-190 (1956)

13. Kikuchi, M., Blackard, W. G., Renold, A. E.: Perifusion of pancreas fragments: a system for study of the dynamic aspects of insulin secretion. Diabetes 23, 550-559 (1974)

14. Kervran, A., Rieutort, M., Guillaume, M.: A simultancous radioimmunoassay for growth hormone and insulin in the plasma of rats and rabbits. Diabete Metab. 2, 67-72 (1976)

15. Girard, J. R., Cuendet, G.S., Marliss, E. B., Kervran, A., Rieutort, M., Assan, R.: Fuels, hormones and liver metabolism at term and during the early postnatal period in the rat. J. Clin. Invest. 52, 3190-3200 (1973)

16. Ottaway, J. H.: Normalization in the fitting of data by iterative methods. Application to tracer kinetics and enzyme kinetics. Biochem. J. 134, 729-736 (1973)

17. Osler, M.: Body fat of newborn infants of diabetic mothers. Acta Endocrinol. (Kbh) 34, 277-286 (1960)

18. Pedersen, J., Bojsen-Møller, B., Poulsen, H.: Blood sugar in newborn infants of diabetic mother. Acta Endocrinol. (Kbh) 15, 33-52 (1954)

19. Farquhar, J. W.: Maternal hyperglycaemia and foetal hyperinsulinism in diabetic pregnancy. Postgrad. Med. J. 38, 612-628 (1962)

20. Pitkin, R. M., Plank, C. J., Filer, L. J. jr.: Fetal and placental composition in experimental maternal diabetes. Proc. Soc. Exp. Biol. Med. 138, 163-166 (1971)

21. Hoet, J. J.: Normal and abnormal foetal weight gain. In: Foetal Autonomy. Ciba Foundation Symposium. Wolstenholme, G. E. W., p. 186-213. London: Churchill 1969

22. Sybulski, S., Maughan, G. B.: Use of streptozotocin as diabetic agent in pregnant rats. Endocrinology 89, 1537-1540 (1971)

23. Prager, R., Abramovici, A., Liban, E., Laron, Z.: Histopathological changes in the placenta of streptozotocin induced diabetic rats. Diabetologia 10, 89-91 (1974)

24. Dubreuil, G., Anderodias, J.: Ilots de Langerhans géants chez un nouveau-né issu de mère glycosurique. C. R. Soc. Biol. (Paris) 83, 1490-1493 (1920) 
25. Van Assche, F. A.: The foetal endocrine pancreas. A quantitative morphological approach. Thesis University of Leuven (1970)

26. Steinke, J., Driscoll, S. G.: The extractable insulin content of pancreas from fetuses and infants of diabetic and control mothers. Diabetes 14, 573-581 (1965)

27. Kozma de Bokay, S., Jacquot, R., Jost, A.: Influence de la pancréatectomie maternelle sur le développement des foetus de rat. J. Physiol. (Paris) 53, 733-740 (1961)

28. Eriksson, U., Andersson, A., Hellerström, C.: Hormone content and insulin biosynthesis in the endocrine pancreas of the offspring of diabetic and subdiabetic rats. Diabetologia 13, 391, (Abst.) (1977)

29. Lazarow, A., Wells, L. J., Carpenter, A. M., Hegre, O., Leonard, R.J., McEvoy, R. C.: Islet differentiation. Organ culture and transplantation. Diabetes 22, 877-912 (1973)

30. Blazquez, E., Lipshaw, L. A., Blazquez, M., Foa, P. P.: Synthesis and release of insulin in fetal nursing and young adult rats. Studies in vivo and in vitro. Pediatr. Res. 9, 17-25 (1975)
31. Kervran, A., Girard, J. R.: Glucose induced increase of plasma insulin in the rat foetus in utero. J. Endocrinol. 62, 545-551 (1974)

32. Kervran, A., Girard, J. R.: Time course of a glucose induced increase in plasma insulin in the rat foetus in utero. J. Endocrinol. 70, 519-520 (1976)

33. Kervran, A., Randon, J., Girard, J. R.: Dynamics of glucose induced insulin release by fetal rat pancreas in vitro: potentiating effect of amino acids. Diabetologia 13, 408, (Abst.) (1977)

Received: April 10, 1978,

and in revised form: June 13, 1978

Dr. A. Kervran

Laboratoire de Physiologie du Développement

Collège de France

Place Marcelin Berthelot

F-75231 Paris Cedex 05

France 